\title{
Purinoceptors, Renal Microvascular Function and Hypertension
}

\author{
Zhengrong GUAN ${ }^{1}$, Mirhan N. MAKLED ${ }^{1}$, Edward W. INSCHO ${ }^{1}$ \\ ${ }^{1}$ Division of Nephrology, Department of Medicine, University of Alabama at Birmingham, \\ Birmingham, Alabama, USA
}

Received March 13, 2019

Accepted March 27, 2020

Epub Ahead of Print April 17, 2020

\section{Summary}

Proper renal blood flow (RBF) and glomerular filtration rate (GFR) are critical for maintaining normal blood pressure, kidney function and water and electrolyte homeostasis. The renal microvasculature expresses a multitude of receptors mediating vasodilation and vasoconstriction, which can influence glomerular blood flow and capillary pressure. Despite this, RBF and GFR remain quite stable when arterial pressure fluctuates because of the autoregulatory mechanism. ATP and adenosine participate in autoregulatory control of RBF and GFR via activation of two different purinoceptor families (P1 and P2). Purinoceptors are widely expressed in renal microvasculature and tubules. Emerging data show altered purinoceptor signaling in hypertension-associated kidney injury, diabetic nephropathy, sepsis, ischemia-reperfusion induced acute kidney injury and polycystic kidney disease. In this brief review, we highlight recent studies and new insights on purinoceptors regulating renal microvascular function and renal hemodynamics. We also address the mechanisms underlying renal microvascular injury and impaired renal autoregulation, focusing on purinoceptor signaling and hypertension-induced renal microvascular dysfunction. Interested readers are directed to several excellent and comprehensive reviews that recently covered the topics of renal autoregulation, and nucleotides in kidney function under physiological and pathophysiological conditions (Inscho 2009, Navar et al. 2008, Carlstrom et al. 2015, Vallon et al. 2020).

\section{Key words}

ATP • Renal autoregulation - Inflammation • Epithelial sodium channel $\bullet$ Reactive oxygen species

\section{Corresponding author}

Z. Guan, Division of Nephrology, Department of Medicine, University of Alabama at Birmingham, 840A Kaul Building, 720 20th Street, South Birmingham, AL 35294, USA. E-mail: zhengrongguan@uabmc.edu

\section{Introduction}

Kidneys constitute less than $1 \%$ of the body weight of healthy adults but receive a blood flow representing approximately $20 \%$ of cardiac output. This high renal blood flow (RBF) per unit organ weight emphasizes the key role for the renal microcirculation in regulating appropriate body fluid volume and composition and maintaining normal blood pressure (BP) (Hall 2015). The renal microcirculation represents a unique portal circulation with the glomerular tuft fed and drained by two resistance arterioles, the afferent and efferent arterioles. Resistance of these arterioles is regulated by neural, hormonal and autocrine/paracrine factors, which are critical for stabilizing $\mathrm{RBF}$ and glomerular filtration rate (GFR) (Navar et al. 2008, Carlstrom et al. 2015).

Under normal conditions, glomerular hydrostatic pressure is maintained relatively constant via the mechanism of renal autoregulation. Renal autoregulation utilizes two primary mechanisms: a local myogenic response and tubuloglomerular feedback (TGF) (Inscho 2009, Navar et al. 2008, Carlstrom et al. 2015, Vallon et al. 2020). Both mechanisms influence afferent arteriole resistance to buffer fluctuations in arterial pressure to protect downstream glomeruli, thereby maintaining stable 
RBF and GFR. Studies also suggest involvement of a third and/or fourth mechanism to effect fine control of glomerular capillary pressure, but those "mechanisms" have not been defined (Just and Arendshorst 2003, Wang et al. 2007, Ren et al. 2007). For example, Just and Arendshorst reported that there was a slower rise of renal vascular resistance (RVR) following the myogenic response while TGF was inhibited with furosemide (Just and Arendshorst 2003). The authors postulated that this slow autoregulatory component, the third mechanism, is TGF-independent, but the nature of this extra component remains unclear. The fourth mechanism is referred to as the connecting tubule-glomerular feedback (CTGF) mechanism (Ren et al. 2007). Unlike the negative loop of the TGF response, the CTGF is a positive feedback mechanism by which increasing $\mathrm{NaCl}$ concentration in the connecting tubule dilates the attached afferent arteriole (Ren et al. 2007). Evidence indicates that autoregulatory effectiveness declines in the early stages of human hypertension (Christensen et al. 1997, 1999, Schjoedt et al. 2009) as well as in hypertensive animal models (Inscho et al. 2004b, Feng et al. 2020). The impaired autoregulatory capacity increases the risk to hypertensive patients for developing chronic kidney disease (CKD).

\section{In vivo and in vitro techniques used for renal autoregulatory studies}

Although the importance of renal autoregulation in kidney function is recognized, technical limitations make it difficult to assess autoregulation in human subjects. Only a few studies have measured GFR during manipulation of mean arterial pressure in hypertensive subjects (Christensen et al. 1997, 2003, Schjoedt et al. 2009). Therefore, most information on renal autoregulation is obtained using animal models. Several in vivo and in vitro techniques are used for assessing renal autoregulatory efficiency. At the whole kidney level, autoregulation of RBF and GFR is usually assessed in response to stepwise-decreases of renal perfusion pressure in anesthetized dogs, rabbits or rats (Navar 1978, Majid et al. 1999, Osmond and Inscho 2010, Fellner et al. 2015). Indirect evidence can be obtained using fiber-optic or needle probes to determine relative regional $\mathrm{RBF}$ measured by dual-channel laser Doppler flowmetry (Roman and Smits 1986). Time/frequency analysis is used to assess myogenic and TGF components in anesthetized animals (Just and Arendshorst 2003). The myogenic response operates at a frequency of $0.1-0.2 \mathrm{~Hz}$ and occurs at approximately $5 \mathrm{~s}$ after a rapid increase in arterial pressure, while TGF operates at a frequency of $0.02-0.04 \mathrm{~Hz}$ and appears at approximately $25 \mathrm{~s}$ after a rapid increase in arterial pressure (Just and Arendshorst 2003). The hydronephrotic kidney is created by ligating the ureter for 6-8 weeks to eliminate TGF, thus isolating myogenic responses (Hayashi et al. 1989). Micropuncture, on the other hand, is useful for assessing TGF in anesthetized rats or mice by measuring proximal tubule stop-flow pressure $\left(\mathrm{P}_{\mathrm{SF}}\right.$; index of glomerular capillary pressure) during manipulation of tubular fluid composition or flow rate to the macula densa (Schnermann et al. 1970, Vallon et al. 2020). Several novel in vitro techniques have been developed to avoid the influences of circulating factors or sympathetic nerve activity (Bencze et al. 2013) or to provide unique access to renal structures. For example, the isolated afferent arteriole with attached macula densa and distal tubule segment is used for investigating TGF signaling (Juncos et al. 1996, Bell et al. 2003, Peti-Peterdi 2006). Microdissected afferent arterioles are used to study myogenic reactivity (Lai et al. 2010, 2011). Since development of the in vitro blood-perfused juxtaglomerular nephron (JMN) technique (Casellas and Navar 1984), we and others applied this approach to study renal autoregulation and renal microvascular reactivity in a variety of rat and mouse models (Navar 1978, Inscho et al. 1990, 2004a, Carmines et al. 1992, Takenaka et al. 1994, Guan et al. 2009, Sorensen et al. 2012, Nagasawa and Imig 2013). With this technique, the kidney is carefully dissected to explore the inner cortical surface and the kidney is perfused with re-constituted blood to approximate in vivo conditions. Notably, afferent arterioles retain endogenous tone and myogenic and TGF responsiveness (Casellas et al. 1985, Moore and Casellas 1990, Takenaka et al. 1994, Guan et al. 2009). More recently, the Bidani et al. (2020) developed a new analytical method to assess renal autoregulation by concurrently collecting RBF data during BP fluctuations in conscious rats.

\section{Myogenic response of renal microvessels}

Bayliss (1902) described the myogenic response more than 100 years ago and noted vasoconstriction or vasodilation in response to increases or decreases in transmural pressure, guarding against traumatic tissue injury from sudden arterial pressure changes. Myogenic 
responsiveness is inherent to vascular smooth muscle and independent of endothelium (Hill et al. 2006). Despite intensive research, the identity, or composition, of the mechanosensor that triggers myogenic responses is unclear, though there are several candidate structures, including epithelial sodium channel (ENaC)-like proteins, transient receptor potential ion channels, and integrins. For more details interested readers can refer to excellent reviews (Hill et al. 2006, Drummond et al. 2008).

Role of epithelial sodium channel (ENaC)-like proteins in the myogenic response

Studies by the Drummond group implicate $\mathrm{ENaC}$ or ENaC-like proteins as mechanosensors regulating myogenic tone (Drummond et al. 2004, Jernigan and Drummond 2005, 2006). Using mouse isolated intrarenal arteries, Jernigan and Drummond (2005, 2006) revealed that myogenic reactivity was abolished by inhibiting degenerin/epithelial $\mathrm{Na}^{+}$channels (DEG/ENaC) with amiloride or benzamil, or was blunted by suppressing $\beta$-ENaC subunits using transfection of $\beta$-ENaC DN-cDNA or siRNA molecules. We applied the in vitro blood-perfused rat JMN preparation with papillectomy to eliminate TGF influences, and also found that amiloride or benzamil attenuated pressure-dependent vasoconstriction of rat afferent arterioles (Guan et al. 2009). Our observation was later confirmed using the same JMN preparation without papillectomy (Nagasawa and Imig 2013). While myogenic reactivity was blunted by pharmacological $\mathrm{ENaC}$ blockade, vasoconstrictor responses to membrane-depolarization $(\mathrm{KCl}), \beta, \gamma$-methylene ATP (P2X1 and P2X3 agonist) or 20-HETE were unaffected (Guan et al. 2009, Nagasawa and Imig 2013), supporting the idea that $\mathrm{ENaC}$, or $\mathrm{ENaC}$-like proteins, may form a mechanosensor-like complex transducing myogenic reactivity. However, studies from hydronephrotic rat kidneys showed opposite results. Indeed, the myogenic response was unaffected by amiloride, and actually enhanced by benzamil (Wang et al. 2008).

$\mathrm{ENaC}$ protein and mRNA expression were detected in renal microvessels and freshly isolated preglomerular microvascular smooth muscle cells (MVSMC) from mice and rats (Jernigan and Drummond 2005, 2006, Guan et al. 2009). Rats express all three $\mathrm{ENaC}$ subunits $(\alpha, \beta$ and $\gamma$-ENaC) in preglomerular MVSMC (Guan et al. 2009), whereas mice only express $\beta$-ENaC and $\gamma$-ENaC (Jernigan and Drummond 2005, 2006). Importantly, mice with reduced $\beta$-ENaC expression showed impaired renal myogenic responsiveness, increased mean arterial pressure, and early signs of inflammation and vascular remodeling (Grifoni et al. 2010, Drummond et al. 2011). These studies strongly project $\mathrm{ENaC}$ or ENaC-like proteins as part of a mechanosensor complex in myogenic reactivity and support a pivotal role for impaired renal autoregulation contributing to kidney injury.

Role of reactive oxygen species (ROS) in the myogenic response

ROS are generated by univalent reduction of oxygen via a number of enzymatic reactions including nicotinamide adenine dinucleotide phosphate (NADPH) oxidase, xanthine oxidase, cyclo-oxygenase, lipoxygenase, mitochondrial electron transport or uncoupled nitric oxide synthase (NOS). ROS, mainly superoxide and hydrogen peroxide $\left(\mathrm{H}_{2} \mathrm{O}_{2}\right)$, were considered damaging molecules produced only during cellular injury, however, growing evidence suggests that ROS may also participate in normal physiological processes and contribute to renal autoregulation (Schnackenberg 2002, Carlstrom et al. 2015). Early studies using isolated-perfused mouse afferent arterioles showed blunted pressure-induced afferent arteriole vasoconstriction in the presence of ROS scavengers like tempol or superoxide dismutase (SOD)-polyethylene glycol (PEG-SOD) (Lai et al. 2010, Lai et al. 2011). Interestingly, myogenic responsiveness was unaffected by PEG-catalase (Lai et al. 2011), suggesting that the myogenic contraction is enhanced by superoxide but not $\mathrm{H}_{2} \mathrm{O}_{2}$. Afferent arterioles exhibit NADPH oxidase (Wilcox 2003, Sharma et al. 2005) and xanthine oxidase activity, but xanthine oxidase activity is lower (Zou et al. 2001). Deletion of the NADPH oxidase subunit, $\mathrm{p} 47^{\text {phox }}$, blunted myogenic reactivity, whereas it was not affected by knockout of endothelial NOS (eNOS) (Lai et al. 2012). This suggests that NADPH oxidase-dependent superoxide production modulates myogenic responses of afferent arterioles independently of eNOS.

\section{Tubuloglomerular feedback (TGF)}

TGF is a unique renal mechanism where tubular and vascular functions are integrated in stabilizing RBF and GFR. TGF arises from the macula densa, a special plaque of cells in the distal convoluted tubule that senses changes in tubular fluid $\mathrm{NaCl}$ concentration and transmits signals to adjust afferent arteriole resistance (Schnermann 2015, Vallon et al. 2020). Although the messenger molecule that signals TGF-resistance adjustments 
remains uncertain, Bell and Peti-Peterdi provided convincing evidence that increases in tubular $\mathrm{NaCl}$ delivery to the macula densa cells triggers ATP release from basolateral membrane (Bell et al. 2003, 2009, PetiPeterdi 2006). The released ATP either acts directly on afferent arterioles via purinergic P2X1 receptors (Bell et al. 2003, Inscho et al. 2003, 2004a, Inscho 2009) or is catabolized to adenosine which activates $\mathrm{A}_{1}$ receptors to increase afferent arteriolar resistance (Just and Arendshorst 2007, Schnermann 2015, Vallon et al. 2020).

\section{Purinoceptors and renal autoregulation}

Despite extensive research, identification of the signaling molecules responsible for renal autoregulatory control remains uncertain. Since the early 1980's, evidence implicates either adenosine, ATP or both as effectors of renal autoregulatory resistance adjustments via purinoceptor activation (Inscho 2009, Bell et al. 2009, Guan et al. 2014, Schnermann 2015, Vallon et al. 2020). Extracellular ATP and adenosine influence cellular function by interacting with two distinct purinoceptor families: P1 and P2 receptors (Burnstock et al. 2014,
North 2016, von Kugelgen 2019). The P1 family includes four subtypes: $\mathrm{A}_{1}, \mathrm{~A}_{2 \mathrm{a}}, \mathrm{A}_{2 \mathrm{~b}}$ and $\mathrm{A}_{3}$ (Fredholm et al. 2000, Klotz 2000). $A_{1}$ and $A_{3}$ receptors are linked to $\mathrm{G}_{\mathrm{o}} / \mathrm{G}_{\mathrm{i}}$ proteins and inhibit adenylyl cyclase, hence decreasing cyclic AMP (cAMP, Fig. 1) (Gerwins and Fredholm 1992). Conversely, $A_{2 a}$ and $A_{2 b}$ receptors are linked to $G_{s}$ proteins and stimulate adenylyl cyclase activity to increase cAMP (Tucker and Linden 1993, Olah 1997). The P2 family is divided into two separate subfamilies: P2X and P2Y (Burnstock et al. 2014, von Kugelgen 2019). P2Y receptors include eight $\mathrm{G}$ protein-coupled receptors $\left(\mathrm{P} 2 \mathrm{Y}_{1}, 2,4,6,11-14\right)$ whereas seven distinct $\mathrm{P} 2 \mathrm{X}$ receptors function as non-selective ion-channels (P2X1-7) (Burnstock et al. 2014, North 2016, von Kugelgen 2019). ATP is an endogenous ligand of $\mathrm{P} 2$ receptors and is rapidly hydrolyzed in vivo into ADP and AMP by widely expressed extracellular nucleotidases (Burnstock et al. 2014, North 2016). AMP is further catabolized by ecto-5'-nucleotidase (ecto-5'NT) or CD73 (cluster of differentiation) to adenosine which acts on $\mathrm{P} 1$ receptors. Activation of membranebound P1 and P2 receptors by nucleosides and nucleotides is illustrated in Figure 1.

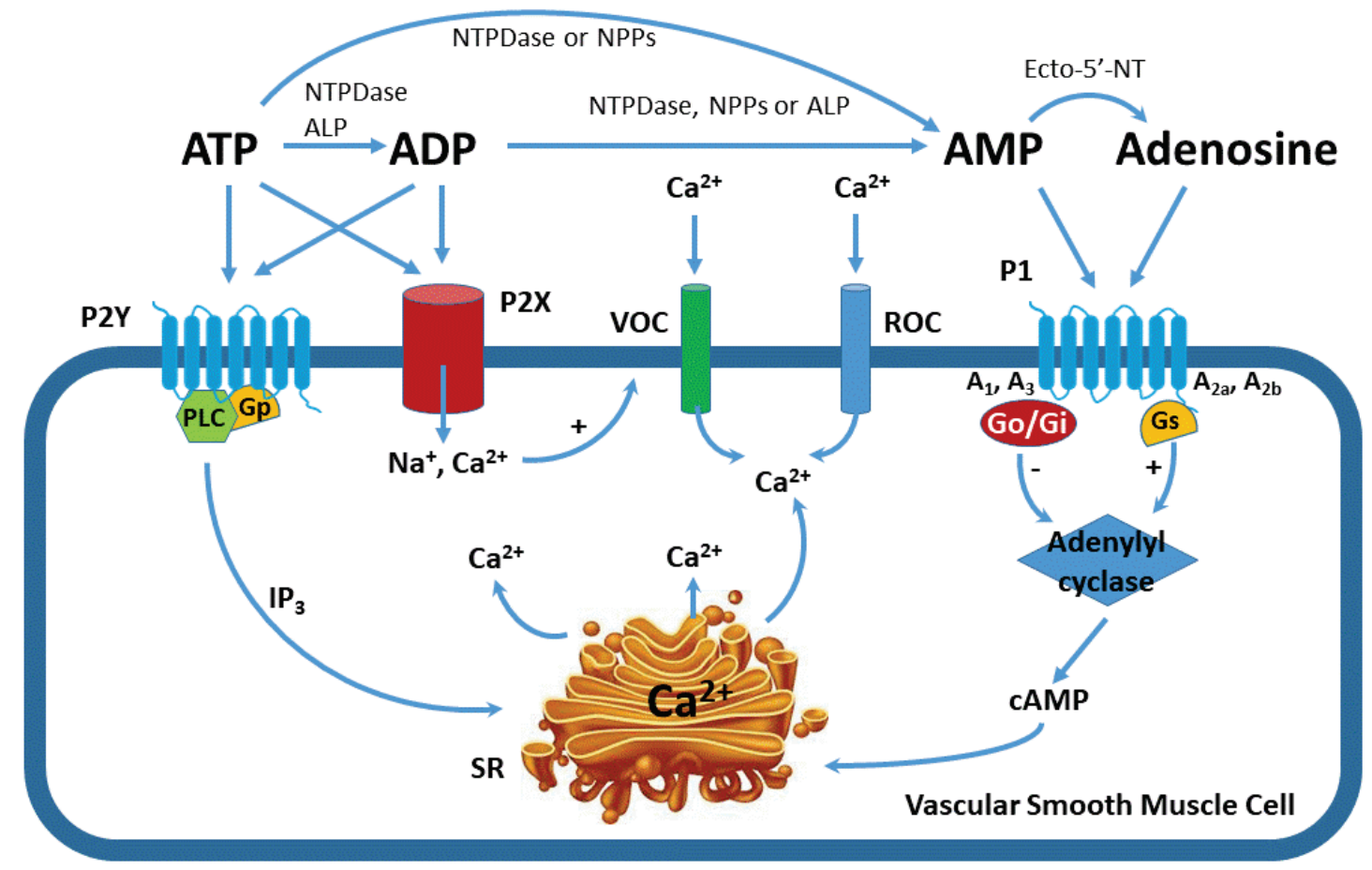

Fig. 1. Signaling pathways for purinoceptor activation in vascular smooth muscle cells. Illustration of the metabolic pathways for ATP to form ADP, AMP, and adenosine by ectonucleotidases. Adenosine and ATP activate P1 and P2 purinoceptors, respectively. The P1 receptor family is comprised of four subtypes: $A_{1}, A_{2 a}, A_{2 b}$ and $A_{3} . A_{1}$ and $A_{3}$ receptors are linked to a $G_{0} / G_{i}$ protein and inhibit adenylyl cyclase, thus decreasing cyclic AMP (CAMP). $A_{2 a}$ and $A_{2 b}$ receptors are linked to $G_{s}$ protein and stimulate adenylyl cyclase to increase cAMP. The P2 receptor family is divided to two distinct subfamilies: P2X and P2Y. P2X receptors function as non-selective ion-channels whereas P2Y receptors are G protein-coupled receptors. Ecto-5'-NT: ecto-5'-nucleotidases; VOC: voltage-operated calcium channel; ROC: receptor-operated calcium channels; NTPDase: nucleoside triphosphate diphosphohydrolase; NPPs, nucleotide pyrophosphatase/phosphodiesterase; ALP: alkaline phosphatase; IP3: inositol 1, 4, 5-trisphosphate, SR: sarcoplasmic reticulum. 


\section{Purinoceptor expression in the renal microvasculature}

Both $\mathrm{P} 1$ and $\mathrm{P} 2$ receptors are widely expressed in the renal microvasculature and in different tubular segments (Schwiebert 2001, Burnstock et al. 2014, Menzies et al. 2015b). For the purpose of this review, we mainly focus on renal microvascular purinoceptor expression and their role in autoregulation. More details regarding $\mathrm{P} 1$ and $\mathrm{P} 2$ receptor expression in glomeruli and tubules can be found in several comprehensive reviews (Burnstock et al. 2014, Menzies et al. 2015b, Vallon et al. 2020). To date, Western blot, RT-PCR and immuno-histochemistry studies demonstrated P2X1, $\mathrm{P} 2 \mathrm{X} 2, \mathrm{P} 2 \mathrm{X} 4, \mathrm{P} 2 \mathrm{X} 7, \mathrm{P} 2 \mathrm{Y}_{1}$ expression and all four $\mathrm{P} 1$ receptor subtypes $\left(\mathrm{A}_{1}, \mathrm{~A}_{2 \mathrm{a}}, \mathrm{A}_{2 \mathrm{~b}}\right.$ and $\left.\mathrm{A}_{3}\right)$ in rat and mouse renal vasculature (Chan et al. 1998, Lewis and Evans 2001, Turner et al. 2003, Menzies et al. 2013, Lu et al. 2015). mRNA for $\mathrm{A}_{1}, \mathrm{~A}_{2 \mathrm{a}}$, and $\mathrm{A}_{2 \mathrm{~b}}$ receptors was also present in rat outer medullary descending vasa recta (Kreisberg et al. 1997). Immunohistochemistry studies revealed that $\mathrm{P} 2 \mathrm{X} 1$ receptors are heavily expressed in MVSMC along the preglomerular vasculature including arcuate, interlobular arteries, and afferent arterioles, but not efferent arterioles (Chan et al. 1998, Turner et al. 2003, Menzies et al. 2013). Lewis and Evans (2001) showed positive immunoreactivity for P2X1 and P2X7 in small and medium rat renal arteries, but negative staining for P2X2, P2X3 and P2X6 receptors. Later, Menzies et al. (2013) reported immune-positive staining for endothelial $\mathrm{P} 2 \mathrm{X} 4$ and $\mathrm{P} 2 \mathrm{X} 7$ receptors in rat preglomerular microvessels. RT-PCR analysis demonstrated expression of genes encoding for P2X1 and $\mathrm{P} 2 \mathrm{X} 4$ receptors, but not for $\mathrm{P} 2 \mathrm{X} 2, \mathrm{P} 2 \mathrm{X} 3, \mathrm{P} 2 \mathrm{X} 5$ and $\mathrm{P} 2 \mathrm{X} 7$ in myocytes isolated from the rat renal vasculature (Harhun et al. 2010).

\section{ATP and/or adenosine in mediating autoregulatory signaling}

Unlike the ATP-mediated vasorelaxation seen in other non-renal vascular beds, ATP vasoconstricts preglomerular microvessels via activation of both $\mathrm{P} 2 \mathrm{X}$ and P2Y receptors (Inscho et al. 2003, 2004a, 2011, Franco et al. 2011, Guan et al. 2013, 2016, Gordienko et al. 2015). Using microdialysis in canine kidneys, Nishiyama et al. (2000, 2001b, 2006) demonstrated a strong positive correlation between renal perfusion pressure and renal interstitial ATP levels but adenosine did not exhibit a similar correlation. Later, several studies (Bell et al. 2003, 2009, Peti-Peterdi 2006) using a single glomerulus with attached macula densa and ATP-sensitive biosensor cells provided convincing evidence that ATP was released directly from the basolateral membrane of macula densa cells in response to an increase in luminal $\mathrm{NaCl}$ concentration. More recently Palygin et al. $(2015,2017)$ applied amperometric ATP sensitive microelectrodes embedded in kidneys to monitor ATP levels in real-time during manipulation of renal perfusion pressure in isolated-perfused rat kidneys or anesthetized rats. They observed an immediate increase of cortical tissue ATP levels when perfusion pressure was increased, consistent with Nishiyama's observations in canine kidneys. Overall, these observations demonstrate that ATP is released in the kidney in response to increases in perfusion pressure, and support the hypothesis that ATP is a mediator of renal autoregulation.

Involvement of $\mathrm{P} 2 \mathrm{X} 1$ receptors in renal autoregulation is further supported by pharmacological and/or genetic intervention studies (Inscho et al. 1996, 2003, 2004a). The earliest work by Inscho et al. (1991, 1992) using the blood-perfused rat or mouse JMN preparation showed that application of ATP or the specific agonist for $\mathrm{P} 2 \mathrm{X} 1$ and $\mathrm{P} 2 \mathrm{X} 3, \beta, \gamma$-methylene ATP, caused rapid and sustained vasoconstriction of afferent arterioles in a concentration-dependent manner but had no detectable impact on efferent arteriole diameter. Pressure-dependent vasoconstriction of afferent arterioles was blunted by application of the P2X1 antagonist, NF279 or by desensitization of P2X1 receptors by repeated superfusion of ATP (Inscho et al. 1996, 2003). Moreover, genetic deletion of P2X1 receptors attenuated pressure-dependent vasoconstriction of afferent arterioles in mice and this inhibition was unaltered by papillotomy or furosemide (Inscho et al. 2003), suggesting that $\mathrm{P} 2 \mathrm{X} 1$ receptors participate in both myogenic and TGF responses. Furthermore, $\mathrm{P} 2 \mathrm{X} 1$ receptor blockade with the non-selective antagonist (PPADS; pyridoxal phosphate-6-azo-benzene2, 4-disulfonic acid) or a selective antagonist (IP5I; P1, P5-Di-inosine-5'-pentaphosphate pentasodium salt) also blunted whole kidney RBF autoregulation in vivo (Osmond and Inscho 2010). Taken together, activation of P2X1 receptors appears essential for autoregulatory responsiveness.

There is compelling evidence supporting adenosine as the mediator of TGF responses 
(Schnermann et al. 1990, Osswald et al. 1997, Ren et al. 2002, Thomson et al. 2000, Hashimoto et al. 2006, $\mathrm{Li}$ et al. 2012, Kim et al. 2015). Adenosine is an endogenous ligand for $\mathrm{P} 1$ receptors. Studies show that application of exogenous adenosine causes biphasic vascular responses at the levels of whole kidney or isolated arteriole (Nishiyama et al. 2001a, Hansen et al. 2005, Lai et al. 2006, Lu et al. 2015). Adenosine vasoconstricts afferent arterioles at low concentrations but evokes vasodilation at higher concentrations (Nishiyama et al. 2001a, Hansen et al. 2005, Lai et al. 2006). This probably reflects activation of different renal microvascular adenosine receptor subtypes. For example, adenosine-mediated vasoconstriction was blunted by $A_{1}$ receptor inhibition or $A_{1}$ receptor gene deletion but was enhanced during $\mathrm{A}_{2}$ receptor blockade (Nishiyama et al. 2001a, Hansen et al. 2005, Lai et al. 2006). Moreover, activation of $A_{1}$ receptors with the selective $\mathrm{A}_{1}$ receptor agonist, $\mathrm{N}^{6}$-cyclohexyladenosine, reduced afferent arteriole diameter while $\mathrm{A}_{2}$ receptor activation with CGS21680, increased afferent arteriole diameter, supporting involvement of $A_{1}$ and $A_{2}$ receptors in regulating afferent arteriole reactivity. Unlike $A_{1}$ and $\mathrm{A}_{2}$ receptors, activation of $\mathrm{A}_{3}$ receptors had no significant effect on isolated mouse afferent arteriole diameter but dilated the afferent arterioles after preconstriction with norepinephrine ( $\mathrm{Lu}$ et al. 2015). Currently the role of $\mathrm{A}_{3}$ receptors in renal microvascular function is unclear, but recent studies suggest that $A_{3}$ receptor inhibition protects against renal ischemia-reperfusion or ureteral obstruction-induced kidney injury (Lee and Emala 2000, Lee et al. 2013).

Although mRNA expression for the four adenosine receptor subtypes is detected in afferent arterioles, animal studies argue that only $\mathrm{A}_{1}$ receptors are involved in the adenosine-mediated TGF response. Alternatively, $\mathrm{A}_{2}$ and $\mathrm{A}_{3}$ receptors might participate in modulating TGF responses. Micropuncture studies show that mouse TGF responses, measured by changes in stopflow pressure, were absent during $A_{1}$ receptor blockade with 8-cyclopentyl-1,3-dipropylxanthine or $\mathrm{A}_{1}$ receptor knockdown (Sun et al. 2001, Hashimoto et al. 2006), implicating adenosine as a mediator of TGF. This is supported by findings that vasoconstrictor responses of afferent arterioles evoked by increased tubular $\mathrm{NaCl}$ delivery to the macula densa was attenuated by selective $\mathrm{A}_{1}$ receptor blockade with FK838 (Ren et al. 2002). Since ecto-5'-NT which degrades AMP to adenosine (Fig. 1) has been detected in the juxtaglomerular apparatus region, the experiments using ectonucleotidase gene deletion or mutation attenuated TGF responses (Castrop et al. 2004, Huang et al. 2006). Moreover, autoregulation of RBF and GFR was impaired in $\mathrm{A}_{1}$ receptor deficient mice (Hashimoto et al. 2006), suggesting that this impairment of renal autoregulation may reflect an abolished TGF mechanism. Collectively, the data support adenosine as a mediator of TGF responses via activation of $A_{1}$ receptors.

\section{Renal autoregulation, inflammation and hypertension}

Typical features of hypertension-induced nephropathy include renal microvascular injury, remodeling, glomerulosclerosis, and/or interstitial fibrosis (Sommers et al. 1958). As discussed above, the renal autoregulatory mechanism prevents transmission of high arterial pressure to glomeruli. In hypertension, loss of appropriate afferent arteriole resistance adjustments leaves glomeruli at risk for elevated glomerular capillary pressure, hyperfiltration, glomerulosclerosis and eventually nephron loss.

\section{Renal autoregulation in hypertensive patients}

According to the National Center for Health Statistics-2011 report (Sebelius et al. 2011), approximately one-third of US adults suffer from hypertension. Meta-analysis revealed a strong correlation between the incidence of hypertension and CKD. Some hypertensive patients, particularly African-Americans are more susceptible to developing CKD than others (Palmer 2004, Kotchen et al. 2000), although the mechanisms contributing to kidney injury are poorly understood. Clinical studies indicate that impaired renal autoregulatory capacity in early stage hypertension might contribute to higher prevalence of hypertension-related chronic vascular disease in African-American individuals than white individuals (Palmer 2004, Kotchen et al. 2000). Human studies also indicate that impaired autoregulatory efficiency in hypertension can occur before structural changes in the renal vasculature (Palmer 2004, Christensen et al. 1999). However, to date there are few studies addressing renal hemodynamic changes in this population. Kotchen et al. (2000) reported that baseline RBF and GFR are higher in African-Americans than white counterparts. GFR was further increased in 
African-Americans after intravenous infusion of norepinephrine despite that RBF was unchanged. This demonstrates glomerular hyperfiltration and impaired GFR autoregulation in African-Americans. Additionally, individuals with impaired autoregulation are predisposed to develop nephropathy in hypertensive subjects (Christensen et al. 1999). That work suggests that lack of efficient autoregulatory control renders glomeruli susceptible to hyperfiltration and hypertensive kidney injury putting the host at high risk for kidney failure, particularly in African-Americans with hypertension (Palmer 2004).

\section{Renal autoregulation in hypertensive animals}

Work in recent decades shows that renal autoregulatory capability is impaired in hypertensive animal models including Ang II, Goldblatt (2K-1C), deoxycorticosterone acetate (DOCA)-salt, the 5/6 renal mass reduction, Fawn-hooded rats and Dahl salt-sensitive (SS) rats (Ploth et al. 1981, Karlsen et al. 1997, Griffin et al. 2004, Burke et al. 2013, Guan et al. 2013, 2016). Impaired autoregulation contributes to hypertensive kidney injury. The molecular pathogenesis underlying hypertension-induced renal microvascular dysfunction is unclear. Sharma et al. (2005) showed that inflammatory factors likely contribute to impaired renal autoregulation in diabetes. Using the blood-perfused JMN preparation, pressure-dependent afferent arteriole vasoconstriction was blunted by an acute 15 min exposure to TGF- $\beta$, but was preserved by simultaneous treatment with ROS scavengers (Tempol or apocynin). Moreover, apocynin blocked the TGF- $\beta$-mediated increase in superoxide production in cultured renal MVSMC, suggesting that inflammatory factors could directly affect renal autoregulatory capacity by increasing superoxide accumulation.

Elegant studies from the Cowley group (Mori and Cowley 2004, Evans et al. 2017) provided compelling evidence that inflammation and renal injury is largely driven by elevation of arterial pressure in Ang IIinfused hypertensive rats or Dahl SS rats fed a $\mathrm{NaCl}$ diet. An aortic clamp was applied between the renal arteries to control the downstream kidney perfusion pressure in the normotensive range while the upstream kidney received hypertensive pressure. After 14-days of treatment, the uncontrolled kidney developed severe glomerular injury, kidney fibrosis and elevated TGF- $\beta$ and NF- $\kappa$ B deposition compared to the controlled kidney. We previously demonstrated that renal autoregulation was impaired in chronic Ang II-infused hypertensive rats as indicated by blunted pressure-dependent afferent arteriole vasoconstriction and the passive pressure/flow relationship (Guan et al. 2010, 2013, Inscho et al. 2011, Osmond et al. 2014). Co-treatment of Ang II-infused hypertensive rats with a nonspecific anti-inflammatory agent, pentosan polysulphate (PPS) (Guan et al. 2010) or a more specific anti-inflammatory agent, mycophenolate mofetil (MMF) (Guan et al. 2013), which suppresses lymphocyte and macrophage infiltration, preserved pressure-dependent vasoconstriction of afferent arterioles (Fig. 2). Consistent with in vitro findings, MMF-treated Ang II-infused rats also exhibited normal whole kidney autoregulation of RBF, reduced plasma TGF- $\beta$ levels and less glomerular injury despite similar hypertensive conditions in Ang II-infused control rats (Guan et al. 2013). This suggests that renal autoregulatory impairment can be at least partially attributed to inflammation. To distinguish if Ang II or hypertension triggers inflammatory cascades, we also examined the impact of PPS treatment in DOCA-salt hypertensive rats, a lowrenin/low-Ang II model (Guan et al. 2016). Similar to findings in Ang II-infused rats, PPS treatment in DOCAsalt rats preserved pressure-dependent vasoconstriction (Fig. 2) and reduced protein and MCP-1 excretion. Collectively, those studies suggest that hypertension triggers inflammatory cascades, leading to impaired renal autoregulatory efficiency and kidney injury involving MCP-1 and/or TGF- $\beta$ signaling pathways.

The Dahl SS rat is a well-characterized hypertensive model, which rapidly develops hypertension and glomerular injury upon high salt (HS) diet feeding. SS rats fed HS also exhibit impaired renal autoregulation (Roman 1986, Takenaka et al. 1992). ETS-1 is a transcription factor targeting the chemokine ligand 2 (CCL2) and mediates vascular inflammatory and fibrotic effects (Zhan et al. 2005). Feng et al. (2015) reported that SS rats with an inactivating mutation of one Ets-1 allele $\left(\mathrm{SS}^{\text {EtsI+/- }}\right.$ rats) developed less severe hypertension in response to $4 \%$ HS feeding compared to normal SS rats. These studies were extended to assess afferent arteriole autoregulatory behavior in $\mathrm{SS}^{\text {EtsI+/- }}$ rats fed HS (7 days). Autoregulatory behavior was determined at a time when BP had just begun to increase but was not statistically different from HS-treated SS rats (Feng et al. 2020). The SS rats receiving a low salt diet exhibited normal autoregulatory reactivity which was lost if the HS diet 
was given. Interestingly, renal autoregulation was preserved in $\mathrm{SS}^{\text {EtsI+/- }}$ rats, even with HS feeding. $\mathrm{SS}^{\text {EtsI+/- }}$ rats also showed less glomerular injury, fibrosis and reduced mRNA expression of CCL2, TGF- $\beta$ and fibronectin in isolated renal microvessels compared to HS-treated SS rats. These observations are consistent with the findings of Elmarakby et al. (2007) showing that pharmacological inhibition of chemokine receptor $2 b$ preserved pressure-induced afferent arteriole vasoconstriction in Ang II-infused hypertensive rats. Overall, these studies reveal that haplo-insufficiency of ETS-1 preserves renal autoregulation in SS rats and that CCL2 in renal microvessels plays an important role in renal pathophysiological alterations in hypertension.

\section{Renal autoregulatory behavior}
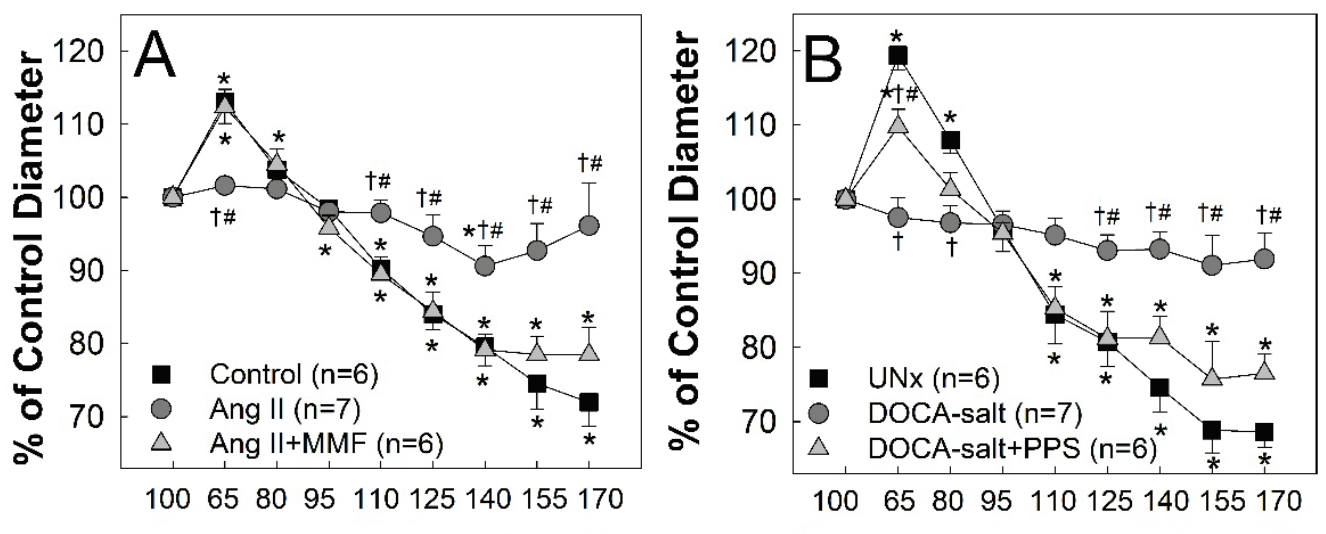

Perfusion Pressure (mmHg)

\section{Perfusion Pressure (mmHg)}

\section{P2X1receptor activation}

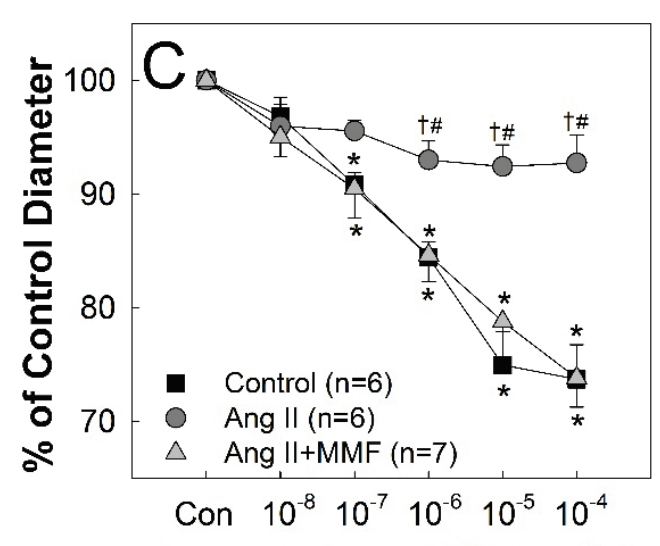

$\beta, \gamma$-methylene ATP ( $\mathrm{mol} / \mathrm{L})$

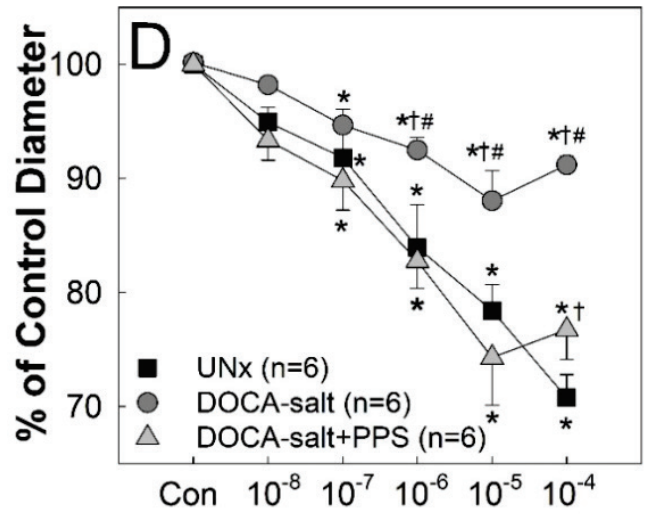

$\beta, \gamma$-methylene ATP (mol/L)

Fig. 2. Afferent arteriole responses to changes in renal perfusion pressure (RPP) and to P2X1 receptor activation in hypertensive rats. (A) Renal autoregulation was assessed by afferent arteriole responses to alterations in RPP in control (squares), Ang II-infused hypertensive rats alone $(60 \mathrm{ng} / \mathrm{min}$, circles) and treated with mycophenolate mofetil (Ang II+MMF, $30 \mathrm{mg} / \mathrm{kg}$.day, triangles). (B) Afferent arteriole autoregulatory responses assessed in rats with uninephrectomy (UNx, squares), DOCA-salt hypertension (circles, a low-renin/low-Ang II model) and DOCA-salt hypertension with pentosan polysulphate treatment (DOCS-salt+PPS, $100 \mathrm{mg} / \mathrm{kg}$. day, triangles). (C) Afferent arteriole responses to increasing concentrations of $\beta, \gamma$-methylene ATP (P2X1 and P2X3 receptor agonist) in control (squares), Ang II-infused alone (circles) and Ang II+MMF (triangles) rats. (D) Afferent arteriole responses to increasing concentrations of $\beta, \gamma$-methylene ATP in UNx (squares), DOCA-salt alone (circles) and DOCA-salt+PPS (triangles) rats. Both hypertensive models exhibit impaired renal autoregulation, indicated by the blunted pressure-dependent afferent arteriole vasoconstriction and also associated with reduced $\beta, \gamma$-methylene ATP reactivity. Anti-inflammatory treatment with MMF or PPS preserved renal autoregulation and vasoconstriction to $\beta, \gamma$-methylene ATP in hypertensive rats without changes in systolic blood pressure (Guan et al. 2013, 2016). Data are normalized as a percent of the control diameter at $100 \mathrm{~mm} \mathrm{Hg}$. Values are expressed as mean \pm SEM. $* P<0.05$ vs. control diameter in the same group; ${ }^{\dagger} P<0.05$ vs. control or UNx at the same RPP; ${ }^{\#} P<0.05$ vs. Ang II+MMF or DOCA-salt+PPS at the same RPP. 
Currently, most methods used for assessing renal autoregulation employ isolated renal microvessels, isolated perfused kidneys, or anesthetized animals. To overcome the influence of anesthesia with isoflurane, and to assess renal autoregulation in a more dynamic state, Bidani et al. (2020) developed a new analytical tool for assessing renal autoregulatory efficiency in conscious rats by calculating short-segment autoregulatory indices (SSARI) using concurrently collected BP and RBF measurements. They determined renal autoregulatory efficiency in rats that underwent uninephrectomy plus $3 / 4$ renal mass reduction (RK-NX). They found that RBF rapidly returned to baseline in 5-10 $\mathrm{s}$ in normal conscious control rats after ambient BP changes. Interestingly, RBF in conscious RK-NX rats also returned to baseline, even in rats receiving a calcium channel blocker. However, it took more time $(\sim 20 \mathrm{~s})$ for RK-NX rats to restore RBF. In contrast, RK-NX rats displayed impaired renal autoregulation under isoflurane anesthesia. The study suggests that previously unrecognized mechanosensitive mechanism(s) which contribute to maintaining stable RBF and GFR in conscious rats can be suppressed by anesthesia. Together, these studies suggest that this slower response may significantly contribute to elevation of glomerular hydrostatic pressure, and hence glomerulosclerosis in hypertension.

\section{Purinoceptors in hypertension-induced renal microvascular dysfunction}

As mentioned earlier, normal autoregulatory control requires $\mathrm{P} 2 \mathrm{X} 1$ and/or $\mathrm{A}_{1}$ receptor signaling (Inscho 2009, Bell et al. 2009, Guan et al. 2014, Schnermann 2015, Vallon et al. 2020). While purinoceptor signaling has recognized roles in regulating cardiovascular function, the pathophysiological implications in hypertension-induced renal microvascular dysfunction remain to be determined. Studies reveal a close relationship between hypertension and $\mathrm{P} 2 \mathrm{X}$ signaling, especially $\mathrm{P} 2 \mathrm{X} 1, \mathrm{P} 2 \mathrm{X} 4$ and $\mathrm{P} 2 \mathrm{X} 7$, in the development of hypertension-associated kidney injury (Inscho et al. 2011, Guan et al. 2014, 2016, Franco et al. 2011, 2017, Ji et al. 2012a, Menzies et al. 2015b). While renal autoregulation is impaired in Ang II-infused or DOCA-salt hypertensive rats, afferent arteriole responses to ATP or the selective P2X1, P2X3 receptor agonist $\beta, \gamma$-methylene ATP were also attenuated (Fig. 2) (Guan et al. 2010, 2013, Inscho et al. 2011). In contrast, afferent arteriole responses to the $\mathrm{P} 1$ receptor agonist, adenosine, or $\mathrm{P}_{2} \mathrm{Y}_{2}$ agonist, UTP, were unchanged in both hypertensive models. PPS or MMF treatment preserved afferent arteriole responses to ATP and $\beta, \gamma$-methylene ATP (Fig. 2), suggesting that inflammation also impairs $\mathrm{P} 2 \mathrm{X} 1$ receptor signaling but has no detectable impact on $\mathrm{A}_{1}$ and $\mathrm{P} 2 \mathrm{Y}_{2}$ receptor activation in afferent arterioles of hypertensive rats (Inscho et al. 2011, Guan et al. 2016). These findings are consistent with the reduction in ATPor $\quad \beta, \gamma$-methylene ATP-mediated intracellular $\mathrm{Ca}^{2+}$ signaling in freshly isolated preglomerular MVSMC of Ang II-infused rats while responses to $\mathrm{KCl}$ remained normal (Inscho et al. 2011). These observations implicate impaired intracellular signaling pathways stimulated by P2X1 receptors in Ang II-hypertensive rats. Surprisingly, $\mathrm{P} 2 \mathrm{X} 1$ receptor protein expression was similar in isolated preglomerular microvessels from control and Ang II-infused rats (Inscho et al. 2011). The explanation for impaired P2X1 receptor activation with no change in $\mathrm{P} 2 \mathrm{X} 1$ receptor protein expression is not understood. Possibly, blunted P2X1-mediated vasoconstriction could reflect elevation of interstitial ATP levels (Graciano et al. 2008), leading to P2X1 receptor desensitization. Micropuncture studies by Franco et al. (2011, 2017) revealed that chronic Ang II infusion increased afferent and efferent arteriole resistance leading to elevation of glomerular pressure and reduction of single nephron GFR. Acute P2 receptor blockade with intra-aortic infusion of PPADS or the P2X1 receptor antagonist, NF449, restored afferent and efferent arteriolar resistance and single nephron GFR to normal in Ang II-infused rats without changes in mean arterial pressure (Franco et al. 2011, 2017). Unlike findings in our study (Inscho et al. 2011), Franco and colleagues found that Ang II-infused rats exhibited significant increases in $\mathrm{P} 2 \mathrm{X} 1$ receptor protein and mRNA expression in cortical tissue. This increased expression could contribute to the increased renal vascular resistance reported.

Additionally, recent studies have shown that P2X7 receptor activation contributes to hypertensionassociated kidney injury in rodents including Ang IIinfused, Dahl SS, DOCA-salt, and Ren-2 transgenic hypertensive rats or mice (Vonend et al. 2004, Ji et al. 2012a, 2012b, Menzies et al. 2015a, Franco et al. 2017). Since P2X7 receptor expression was detected in the endothelium of preglomerular arteries, the vascular smooth muscle layer of afferent arterioles and the vasa recta, Menzies et al. (2015a, 2015b) proposed that chronic Ang II infusion promoted P2X7 receptor activation which contributed to renal microvascular 
dysfunction and reduction of medullary perfusion. Indeed, the authors found that chronic, low-dose Ang II infusion in F344 rats led to increased P2X7 receptor expression in the vascular smooth muscle of preglomerular arteries along with a significant reduction of medullary perfusion. This occurred despite mean BP rising by only $\sim 15 \mathrm{~mm} \mathrm{Hg}$ and no detectable albuminuria. P2X7 receptor blockade with the specific antagonist AZ11657312 increased medullary blood flow, improved pressure-natriuresis and reduced glomerular macrophage infiltration via a NO-dependent mechanism (Menzies et al. 2015a), suggesting that activation of $\mathrm{P} 2 \mathrm{X} 7$ receptor signaling by Ang II induces renal microvascular dysfunction and inflammation. This study is consistent with findings in Dahl SS rats fed an $8 \%$ HS diet demonstrating a role for $\mathrm{P} 2 \mathrm{X} 7$ receptors in the development of hypertension and kidney injury ( $\mathrm{Ji}$ et al. 2012a). Ji et al. (2012a) showed that treatment with selective P2X7 receptor antagonists (BBG or A438079) not only decreased systolic BP but also mitigated kidney injury in Dahl SS rats. Furthermore, Franco et al. (2017) reported that $\mathrm{P} 2 \mathrm{X} 7$ receptor blockade reduced afferent and efferent arteriolar resistance and restored single nephron GFR in Ang II-infused hypertensive rats, similar to P2X1 blockade. Together, those studies suggest that $\mathrm{P} 2 \mathrm{X} 7$ receptor signaling is upregulated in hypertension. Inhibiting $\mathrm{P} 2 \mathrm{X} 7$ receptor activation protects against hypertensive injury by normalizing renal microvascular resistance and hemodynamics.

In summary, clinical studies indicate a strong correlation between the incidence of hypertension and kidney injury/failure, particularly in African-American hypertensive patients. The underlying processes for hypertension-associated pathological renal changes may involve multiple factors such as genetics, severe hypertension, aging, sex, etc. Emerging clinical data indicate that renal autoregulatory impairment may play a critical role in some hypertensive patients who develop kidney injury and end-stage kidney disease more rapidly than others. Here, we also present evidence from animal studies demonstrating that activation of inflammatory cascades contribute to hypertension-induced renal microvascular dysfunction manifested as reduced pressure-mediated adjustments in afferent arteriole diameter and reduced responsiveness to $\mathrm{P} 2 \mathrm{X} 1$ receptor activation. Compromised autoregulatory efficiency leads to glomerular hyperfiltration and promotes progression of glomerulosclerosis in hypertensive subjects. Furthermore, P2X7 receptor activation plays a key role in renal microvascular dysfunction and inflammation. Thus, it is vital to unravel the mechanisms underlying hypertensionmediated renal injury, and to develop effective, targeted, therapeutic interventions which could prevent, or delay, progressive renal decline.

\section{Conflict of Interest}

There is no conflict of interest.

\section{Acknowledgements}

This work was supported in part by NIH R01 (DK106500) to Guan Z. and by NIH R01 (DK044628) to Inscho EW.

\section{References}

BAYLISS WM: On the local reactions of the arterial wall to changes of internal pressure. J Physiol 28: 220-231, 1902. https://doi.org/10.1113/jphysiol.1902.sp000911

BELL PD, LAPOINTE JY, SABIROV R, HAYASHI S, PETI-PETERDI J, MANABE K, KOVACS G, OKADA Y: Macula densa cell signaling involves ATP release through a maxi anion channel. Proc Natl Acad Sci U S A 100: 4322-4327, 2003. https://doi.org/10.1073/pnas.0736323100

BELL PD, KOMLOSI P, ZHANG ZR: ATP as a mediator of macula densa cell signalling. Purinergic Signal 5: 461-471, 2009. https://doi.org/10.1007/s11302-009-9148-0

BENCZE M, BEHULIAK M, ZICHA J: The impact of four different classes of anesthetics on the mechanisms of blood pressure regulation in normotensive and spontaneously hypertensive rats. Physiol Res 62: 471-478, 2013.

BIDANI AK, POLICHNOWSKI AJ, LICEA-VARGAS H, LONG J, KLIETHERMES S, WILLIAMSON GA, GRIFFIN KA: BP Fluctuations and the real-time dynamics of renal blood flow responses in conscious rats. J Am Soc Nephrol 31: 324-336, 2020. https://doi.org/10.1681/asn.2019070718

BURKE M, PABBIDI M, FAN F, GE Y, LIU R, WILLIAMS JM, SARKIS A, LAZAR J, JACOB HJ, ROMAN RJ: Genetic basis of the impaired renal myogenic response in FHH rats. Am J Physiol Renal Physiol 304 : F565-F577, 2013. https://doi.org/10.1152/ajprenal.00404.2012 
BURNSTOCK G, EVANS LC, BAILEY MA: Purinergic signalling in the kidney in health and disease. Purinergic Signal 10: 71-101, 2014. https://doi.org/10.1007/s11302-013-9400-5

CARLSTROM M, WILCOX CS, ARENDSHORST WJ: Renal autoregulation in health and disease. Physiol Rev 95: 405-511, 2015. https://doi.org/10.1152/physrev.00042.2012

CARMINES PK, MITCHELL KD, NAVAR LG: Effects of calcium antagonists on renal hemodynamics and glomerular function. Kidney Int 41 (Suppl 36): S43-S48, 1992.

CASELLAS D, NAVAR LG: In vitro perfusion of juxtamedullary nephrons in rats. Am J Physiol Renal Physiol 246 : F349-F358, 1984. https://doi.org/10.1152/ajprenal.1984.246.3.f349

CASELLAS D, CARMINES PK, NAVAR LG: Microvascular reactivity of in vitro blood perfused juxtamedullary nephrons from rats. Kidney Int 28: 752-759, 1985. https://doi.org/10.1038/ki.1985.194

CASTROP H, HUANG Y, HASHIMOTO S, MIZEL D, HANSEN P, THEILIG F, BACHMANN S, DENG C, BRIGGS J, SCHNERMANN J: Impairment of tubuloglomerular feedback regulation of GFR in ecto-5'nucleotidase/CD73-deficient mice. J Clin Invest 114: 634-642, 2004. https://doi.org/10.1172/jci21851

CHAN CM, UNWIN RJ, BARDINI M, OGLESBY IB, FORD AP, TOWNSEND-NICHOLSON A, BURNSTOCK G: Localization of P2X1 purinoceptors by autoradiography and immunohistochemistry in rat kidneys. Am J Physiol Renal Physiol 274: F799-F804, 1998. https://doi.org/10.1152/ajprenal.1998.274.4.f799

CHRISTENSEN PK, HANSEN HP, PARVING HH: Impaired autoregulation of GFR in hypertensive non-insulin dependent diabetic patients. Kidney Int 52: 1369-1374, 1997. https://doi.org/10.1038/ki.1997.463

CHRISTENSEN PK, HOMMEL EE, CLAUSEN P, FELDT-RASMUSSEN B, PARVING HH: Impaired autoregulation of the glomerular filtration rate in patients with nondiabetic nephropathies. Kidney Int 56: 1517-1523, 1999. https://doi.org/10.1046/j.1523-1755.1999.00676.x

CHRISTENSEN PK, AKRAM K, KONIG KB, PARVING HH: Autoregulation of glomerular filtration rate in patients with type 2 diabetes during isradipine therapy. Diabetes Care 26: 156-162, 2003. https://doi.org/10.2337/diacare.26.1.156

DRUMMOND HA, GEBREMEDHIN D, HARDER DR: Degenerin/epithelial $\mathrm{Na}^{+}$channel proteins: components of a vascular mechanosensor. Hypertension 44: 643-648, 2004. https://doi.org/10.1161/01.hyp.0000144465.56360.ad

DRUMMOND HA, GRIFONI SC, JERNIGAN NL: A new trick for an old dogma: ENaC proteins as mechanotransducers in vascular smooth muscle. Physiology (Bethesda) 23: 23-31, 2008. https://doi.org/10.1152/physiol.00034.2007

DRUMMOND HA, GRIFONI SC, ABU-ZAID A, GOUSSET M, CHIPOSI R, BARNARD JM, MURPHEY B, STEC DE: Renal inflammation and elevated blood pressure in a mouse model of reduced $\beta$-ENaC. Am J Physiol Renal Physiol 301: F443-F449, 2011. https://doi.org/10.1152/ajprenal.00694.2010

ELMARAKBY AA, QUIGLEY JE, OLEARCZYK JJ, SRIDHAR A, COOK AK, INSCHO EW, POLLOCK DM, IMIG JD: Chemokine receptor $2 \mathrm{~b}$ inhibition provides renal protection in angiotensin II-salt hypertension. Hypertension 50: 1069-1076, 2007. https://doi.org/10.1161/hypertensionaha.107.098806

EVANS LC, PETROVA G, KURTH T, YANG C, BUKOWY JD, MATTSON DL, COWLEY AWJ: Increased perfusion pressure drives renal T-cell infiltration in the Dahl salt-sensitive rat. Hypertension 70: 543-551, 2017. https://doi.org/10.1161/hypertensionaha.117.09208

FELLNER RC, GUAN Z, COOK AK, POLLOCK DM, INSCHO EW: Endothelin contributes to blunted renal autoregulation observed with a high-salt diet. Am J Physiol Renal Physiol 309: F687-F696, 2015. https://doi.org/10.1152/ajprenal.00641.2014

FENG W, CHUMLEY P, PRIETO MC, MIYADA K, SETH DM, FATIMA H, HUA P, REZONZEW G, SANDERS PW, JAIMES EA: Transcription factor avian erythroblastosis virus E26 oncogen homolog-1 is a novel mediator of renal injury in salt-sensitive hypertension. Hypertension 65: 813-820, 2015. https://doi.org/10.1161/hypertensionaha.114.04533

FENG W, GUAN Z, XING D, LI X, YING WZ, REMEDIES CE, INSCHO EW, SANDERS PW: Avian erythroblastosis virus E26 oncogene homolog-1 (ETS-1) plays a role in renal microvascular pathophysiology in the Dahl salt-sensitive rat. Kidney Int 97: 528-537, 2020. https://doi.org/10.1016/j.kint.2019.09.025 
FRANCO M, BAUTISTA R, TAPIA E, SOTO V, SANTAMARIA J, OSORIO H, PACHECO U, SANCHEZLOZADA LG, KOBORI H, NAVAR LG: Contribution of renal purinergic receptors to renal vasoconstriction in angiotensin II-induced hypertensive rats. Am J Physiol Renal Physiol 300: F1301-F1309, 2011. https://doi.org/10.1152/ajprenal.00367.2010

FRANCO M, BAUTISTA-PEREZ R, CANO-MARTINEZ A, PACHECO U, SANTAMARIA J, DEL VALLE MONDRAGON L, PEREZ-MENDEZ O, NAVAR LG: Physiopathological implications of P2X1 and P2X7 receptors in regulation of glomerular hemodynamics in angiotensin II-induced hypertension. Am J Physiol Renal Physiol 313: F9-F19, 2017. https://doi.org/10.1152/ajprenal.00663.2016

FREDHOLM BB, ARSLAN G, HALLDNER L, KULL B, SCHULTE G, WASSERMAN W: Structure and function of adenosine receptors and their genes. Naunyn Schmiedebergs Arch Pharmacol 362: 364-374, 2000. https://doi.org/10.1007/s002100000313

GERWINS P, FREDHOLM BB: Stimulation of adenosine A1 receptors and bradykinin receptors, which act via different $G$ proteins, synergistically raises inositol 1,4,5-trisphosphate and intracellular free calcium in DDT1 MF-2 smooth muscle cells. Proc Natl Acad Sci U S A 89: 7330-7334, 1992. https://doi.org/10.1073/pnas.89.16.7330

GORDIENKO D, POVSTYAN O, SUKHANOVA K, RAPHAEL M, HARHUN M, DYSKINA Y, LEHEN'KYI V, JAMA A, LU ZL, SKRYMA R, PREVARSKAYA N: Impaired P2X signalling pathways in renal microvascular myocytes in genetic hypertension. Cardiovasc Res 105: 131-142, 2015. https://doi.org/10.1093/cvr/cvu249

GRACIANO ML, NISHIYAMA A, JACKSON K, SETH DM, ORTIZ RM, PRIETO-CARRASQUERO MC, KOBORI H, NAVAR LG: Purinergic receptors contribute to early mesangial cell transformation and renal vessel hypertrophy during angiotensin II-induced hypertension. Am J Physiol Renal Physiol 294: F161-F169, 2008. https://doi.org/10.1152/ajprenal.00281.2007

GRIFFIN KA, PICKEN MM, BIDANI AK: Blood pressure lability and glomerulosclerosis after normotensive 5/6 renal mass reduction in the rat. Kidney Int 65: 209-218, 2004. https://doi.org/10.1111/j.1523-1755.2004.00356.x

GRIFONI SC, CHIPOSI R, MCKEY SE, RYAN MJ, DRUMMOND HA: Altered whole kidney blood flow autoregulation in a mouse model of reduced beta-ENaC. Am J Physiol Renal Physiol 298: F285-F292, 2010. https://doi.org/10.1152/ajprenal.00496.2009

GUAN Z, POLLOCK JS, COOK AK, HOBBS JL, INSCHO EW: Effect of epithelial sodium channel blockade on the myogenic response of rat juxtamedullary afferent arterioles. Hypertension 54: 1062-1069, 2009. https://doi.org/10.1161/hypertensionaha.109.137992

GUAN Z, FULLER BS, YAMAMOTO T, COOK AK, POLLOCK JS, INSCHO EW: Pentosan polysulfate treatment preserves renal autoregulation in Ang II-infused hypertensive rats via normalization of P2X1 receptor activation. Am J Physiol Renal Physiol 298: F1276-F1284, 2010. https://doi.org/10.1152/ajprenal.00743.2009

GUAN Z, GIDDENS MI, OSMOND DA, COOK AK, HOBBS JL, ZHANG S, YAMAMOTO T, POLLOCK JS, POLLOCK DM, INSCHO EW: Immunosuppression preserves renal autoregulatory function and microvascular P2X1 receptor reactivity in ANG II-hypertensive rats. Am J Physiol Renal Physiol 304: F801-F807, 2013. https://doi.org/10.1152/ajprenal.00286.2012

GUAN Z, FELLNER RC, VAN BEUSECUM J, INSCHO EW: P2 receptors in renal autoregulation. Curr Vasc Pharmacol 12: 818-828, 2014. https://doi.org/10.2174/15701611113116660152

GUAN Z, SINGLETARY ST, CHA H, VAN BEUSECUM JP, COOK AK, POLLOCK JS, POLLOCK DM, INSCHO EW: Pentosan polysulfate preserves renal microvascular P2X1 receptor reactivity and autoregulatory behavior in DOCA-salt hypertensive rats. Am J Physiol Renal Physiol 310: F456-F465, 2016. https://doi.org/10.1152/ajprenal.00110.2015

HALL JE: The body fluids and kidneys. In: Guyton and Hall Textbook of Medical Physiology. Elsevier, Philadelphia, 2015, pp. 305-440.

HANSEN PB, HASHIMOTO S, OPPERMANN M, HUANG Y, BRIGGS JP, SCHNERMANN J: Vasoconstrictor and vasodilator effects of adenosine in the mouse kidney due to preferential activation of A1 or A2 adenosine receptors. J Pharmacol Exp Ther 315: 1150-1157, 2005. https://doi.org/10.1124/jpet.105.091017 
HARHUN MI, POVSTYAN OV, GORDIENKO DV: Purinoreceptor-mediated current in myocytes from renal resistance arteries. Br J Pharmacol 160: 987-997, 2010. https://doi.org/10.1111/j.1476-5381.2010.00714.x

HASHIMOTO S, HUANG Y, BRIGGS J, SCHNERMANN J: Reduced autoregulatory effectiveness in adenosine 1 receptor-deficient mice. Am J Physiol Renal Physiol 290: F888-F891, 2006. https://doi.org/10.1152/ajprenal.00381.2005

HAYASHI K, EPSTEIN M, LOUTZENHISER R: Pressure-induced vasoconstriction of renal microvessels in normotensive and hypertensive rats. Studies in the isolated perfused hydronephrotic kidney. Circ Res 65: 1475-1484, 1989. https://doi.org/10.1161/01.res.65.6.1475

HILL MA, DAVIS MJ, MEININGER GA, POTOCNIK SJ, MURPHY TV: Arteriolar myogenic signalling mechanisms: Implications for local vascular function. Clin Hemorheol Microcirc 34: 67-79, 2006.

HUANG DY, VALLON V, ZIMMERMANN H, KOSZALKA P, SCHRADER J, OSSWALD H: Ecto-5'-nucleotidase (cd73)-dependent and -independent generation of adenosine participates in the mediation of tubuloglomerular feedback in vivo. Am J Physiol Renal Physiol 291: F282-F288, 2006. https://doi.org/10.1152/ajprenal.00113.2005

INSCHO EW: Mysteries of renal autoregulation. Hypertension 53: 299-306, 2009. https://doi.org/10.1161/hypertensionaha.108.119982

INSCHO EW, CARMINES PK, COOK AK, NAVAR LG: Afferent arteriolar responsiveness to altered perfusion pressure in renal hypertension. Hypertension 15: 748-752, 1990. https://doi.org/10.1161/01.hyp.15.6.748

INSCHO EW, CARMINES PK, NAVAR LG: Juxtamedullary afferent arteriolar responses to P1 and P2 purinergic stimulation. Hypertension 17: 1033-1037, 1991. https://doi.org/10.1161/01.hyp.17.6.1033

INSCHO EW, OHISHI K, NAVAR LG: Effects of ATP on pre- and postglomerular juxtamedullary microvasculature. Am J Physiol Renal Physiol 263: F886-F893, 1992. https://doi.org/10.1152/ajprenal.1992.263.5.1886

INSCHO EW, COOK AK, NAVAR LG: Pressure-mediated vasoconstriction of juxtamedullary afferent arterioles involves P2-purinoceptor activation. Am J Physiol Renal Physiol 271: F1077-F1085, 1996. https://doi.org/10.1152/ajprenal.1996.271.5.f1077

INSCHO EW, COOK AK, IMIG JD, VIAL C, EVANS RJ: Physiological role for P2X1 receptors in renal microvascular autoregulatory behavior. J Clin Invest 112: 1895-1905, 2003. https://doi.org/10.1172/jci18499

INSCHO EW, COOK AK, IMIG JD, VIAL C, EVANS RJ: Renal autoregulation in P2X1 knockout mice. Acta Physiol Scand 181: 445-453, 2004a. https://doi.org/10.1111/j.1365-201x.2004.01317.x

INSCHO EW, COOK AK, MURZYNOWSKI JB, IMIG JD: Elevated arterial pressure impairs autoregulation independently of $\mathrm{AT}_{1}$ receptor activation. J Hypertens 22: 811-818, 2004b. https://doi.org/10.1097/00004872$\underline{200404000-00025}$

INSCHO EW, COOK AK, ANDREA N. CLARKE, ZHANG S, GUAN Z: P2X1 receptor-mediated vasoconstriction of afferent arterioles in Ang II-infused hypertensive rats fed a high salt diet. Hypertension 57: 780-787, 2011. https://doi.org/10.1161/hypertensionaha.110.168955

JERNIGAN NL, DRUMMOND HA: Vascular ENaC proteins are required for renal myogenic constriction. Am J Physiol Renal Physiol 289: F891-F901, 2005. https://doi.org/10.1152/ajprenal.00019.2005

JERNIGAN NL, DRUMMOND HA: Myogenic vasoconstriction in mouse renal interlobar arteries: role of endogenous beta and gammaENaC. Am J Physiol Renal Physiol 291: F1184-F1191, 2006. https://doi.org/10.1152/ajprenal.00177.2006

JI X, NAITO Y, HIROKAWA G, WENG H, HIURA Y, TAKAHASHI R, IWAI N: P2X7 receptor antagonism attenuates the hypertension and renal injury in Dahl salt-sensitive rats. Hypertens Res 35: 173-179, $2012 \mathrm{a}$. https://doi.org/10.1038/hr.2011.153

JI X, NAITO Y, WENG H, ENDO K, MA X, IWAI N: P2X7 deficiency attenuates hypertension and renal injury in deoxycorticosterone acetate-salt hypertension. Am J Physiol Renal Physiol 303: F1207-F1215, 2012 b. https://doi.org/10.1152/ajprenal.00051.2012

JUNCOS LA, REN Y, ARIMA S, GARVIN J, CARRETERO OA, ITO S: Angiotensin II action in isolated microperfused rabbit afferent arterioles is modulated by flow. Kidney Int 49: 374-381, 1996. https://doi.org/10.1038/ki.1996.55 
JUST A, ARENDSHORST WJ: Dynamics and contribution of mechanisms mediating renal blood flow autoregulation. Am J Physiol Regul Integr Comp Physiol 285: R619-R631, 2003. https://doi.org/10.1152/ajpregu.00766.2002

JUST A, ARENDSHORST WJ: A novel mechanism of renal blood flow autoregulation and the autoregulatory role of A1 adenosine receptors in mice. Am J Physiol Renal Physiol 293: F1489-F1500, 2007. https://doi.org/10.1152/ajprenal.00256.2007

KARLSEN FM, ANDERSEN CB, LEYSSAC PP, HOLSTEIN-RATHLOU NH: Dynamic autoregulation and renal injury in Dahl rats. Hypertension 30: 975-983, 1997. https://doi.org/10.1161/01.hyp.30.4.975

KIM SM, MIZEL D, QIN Y, HUANG Y, SCHNERMANN J: Blood pressure, heart rate and tubuloglomerular feedback in A1AR-deficient mice with different genetic backgrounds. Acta Physiol (Oxf) 213: 259-267, 2015. https://doi.org/10.1111/apha.12377

KLOTZ KN: Adenosine receptors and their ligands. Naunyn Schmiedebergs Arch Pharmacol 362: 382-391, 2000. https://doi.org/10.1007/s002100000315

KOTCHEN TA, PIERING AW, COWLEY AW, GRIM CE, GAUDET D, HAMET P, KALDUNSKI ML, KOTCHEN JM, ROMAN RJ: Glomerular hyperfiltration in hypertensive African Americans. Hypertension 35: 822-826, 2000. https://doi.org/10.1161/01.hyp.35.3.822

KREISBERG MS, SILLDORFF EP, PALLONE TL: Localization of adenosine-receptor subtype mRNA in rat outer medullary descending vasa recta by RT-PCR. Am J Physiol 272: H1231-H1238, 1997. https://doi.org/10.1152/ajpheart.1997.272.3.h1231

LAI EY, PATZAK A, STEEGE A, MROWKA R, BROWN R, SPIELMANN N, PERSSON PB, FREDHOLM BB, PERSSON AE: Contribution of adenosine receptors in the control of arteriolar tone and adenosine-angiotensin II interaction. Kidney Int 70: 690-698, 2006. https://doi.org/10.1038/sj.ki.5001650

LAI EY, ONOZATO ML, SOLIS G, ASLAM S, WELCH WJ, WILCOX CS: Myogenic responses of mouse isolated perfused renal afferent arterioles: effects of salt intake and reduced renal mass. Hypertension 55: 983-989, 2010. https://doi.org/10.1161/hypertensionaha.109.149120

LAI EY, WELLSTEIN A, WELCH WJ, WILCOX CS: Superoxide modulates myogenic contractions of mouse afferent arterioles. Hypertension 58: 650-656, 2011. https://doi.org/10.1161/hypertensionaha.111.170472

LAI EY, SOLIS G, LUO Z, CARLSTROM M, SANDBERG K, HOLLAND S, WELLSTEIN A, WELCH WJ, WILCOX CS: p47(phox) is required for afferent arteriolar contractile responses to angiotensin II and perfusion pressure in mice. Hypertension 59: 415-420, 2012. https://doi.org/10.1161/hypertensionaha.111.184291

LEE HT, EMALA CW: Protective effects of renal ischemic preconditioning and adenosine pretreatment: role of $\mathrm{A}(1)$ and $\mathrm{A}(3)$ receptors. Am $\mathrm{J}$ Physiol Renal Physiol 278: F380-F387, 2000. https://doi.org/10.1152/ajprenal.2000.278.3.f380

LEE J, HWANG I, LEE JH, LEE HW, JEONG LS, HA H: The selective A3AR antagonist LJ-1888 ameliorates UUO-induced tubulointerstitial fibrosis. Am J Pathol 183: 1488-1497, 2013. https://doi.org/10.1016/j.ajpath.2013.07.010

LEWIS CJ, EVANS RJ: P2X receptor immunoreactivity in different arteries from the femoral, pulmonary, cerebral, coronary and renal circulations. J Vasc Res 38: 332-340, 2001. https://doi.org/10.1159/000051064

LI L, LAI EY, HUANG Y, EISNER C, MIZEL D, WILCOX CS, SCHNERMANN J: Renal afferent arteriolar and tubuloglomerular feedback reactivity in mice with conditional deletions of adenosine 1 receptors. Am J Physiol Renal Physiol 303: F1166-F1175, 2012. https://doi.org/10.1152/ajprenal.00222.2012

LU Y, ZHANG R, GE Y, CARLSTROM M, WANG S, FU Y, CHENG L, WEI J, ROMAN RJ, WANG L, GAO X, LIU R: Identification and function of adenosine A3 receptor in afferent arterioles. Am J Physiol Renal Physiol 308: F1020-F1025, 2015. https://doi.org/10.1152/ajprenal.00422.2014

MAJID DS, INSCHO EW, NAVAR LG: P2 purinoceptor saturation by adenosine triphosphate impairs renal autoregulation in dogs. J Am Soc Nephrol 10: 492-498, 1999.

MENZIES RI, UNWIN RJ, DASH RK, BEARD DA, COWLEY AW JR, CARLSON BE, MULLINS JJ, BAILEY MA: Effect of P2X4 and P2X7 receptor antagonism on the pressure diuresis relationship in rats. Front Physiol 4: 305, 2013. https://doi.org/10.3389/fphys.2013.00305 
MENZIES RI, HOWARTH AR, UNWIN RJ, TAM FW, MULLINS JJ, BAILEY MA: Inhibition of the purinergic P2X7 receptor improves renal perfusion in angiotensin-II-infused rats. Kidney Int 88: 1079-1087, $2015 \mathrm{a}$. https://doi.org/10.1038/ki.2015.182

MENZIES RI, UNWIN RJ, BAILEY MA: Renal P2 receptors and hypertension. Acta Physiol (Oxf) 213: 232-241, 2015b. https://doi.org/10.1111/apha.12412

MOORE LC, CASELLAS D: Tubuloglomerular feedback dependence of autoregulation in rat juxtamedullary afferent arterioles. Kidney Int 37: 1402-1408, 1990. https://doi.org/10.1038/ki.1990.129

MORI T, COWLEY AW JR: Role of pressure in angiotensin II-induced renal injury: chronic servo-control of renal $\begin{array}{llllll}\text { perfusion } & \text { pressure } & \text { in }\end{array}$ https://doi.org/10.1161/01.hyp.0000120971.49659.6a

NAGASAWA T, IMIG JD: Afferent arteriolar responses to beta,gamma-methylene ATP and 20-HETE are not blocked by ENaC inhibition. Physiol Rep 1: e00082, 2013. https://doi.org/10.1002/phy2.82

NAVAR LG: Renal autoregulation: perspectives from whole kidney and single nephron studies. Am J Physiol 234: F357-F370, 1978. https://doi.org/10.1152/ajprenal.1978.234.5.f357

NAVAR LG, ARENDSHORST WJ, PALLONE TL, INSCHO EW, IMIG JD, BELL PD: The renal microcirculation. In: Comprehensive Physiology. TUMA RF, DURAN WN, LEY K (eds), Elsevier, San Diego, 2008, pp 550-683. https://doi.org/10.1016/b978-0-12-374530-9.00015-2

NISHIYAMA A, MAJID DS, TAHER KA, MIYATAKE A, NAVAR LG: Relation between renal interstitial ATP concentrations and autoregulation-mediated changes in renal vascular resistance. Circ Res 86: 656-662, 2000. https://doi.org/10.1161/01.res.86.6.656

NISHIYAMA A, INSCHO EW, NAVAR LG: Interactions of adenosine A1 and A2a receptors on renal microvascular reactivity. Am J Physiol Renal Physiol 280: F406-F414, 2001a. https://doi.org/10.1152/ajprenal.2001.280.3.f406

NISHIYAMA A, MAJID DS, WALKER M 3RD, MIYATAKE A, NAVAR LG: Renal interstitial ATP responses to changes in arterial pressure during alterations in tubuloglomerular feedback activity. Hypertension 37 : 753-759, 2001b. https://doi.org/10.1161/01.hyp.37.2.753

NISHIYAMA A, JACKSON KE, MAJID DS, RAHMAN M, NAVAR LG: Renal interstitial fluid ATP responses to arterial pressure and tubuloglomerular feedback activation during calcium channel blockade. Am J Physiol Heart Circ Physiol 290: H772-H777, 2006. https://doi.org/10.1152/ajpheart.00242.2005

NORTH RA: P2X receptors. Philos Trans R Soc Lond B Biol Sci 371: 20150427, 2016. https://doi.org/10.1098/rstb.2015.0427

OLAH ME: Identification of A2a adenosine receptor domains involved in selective coupling to Gs. Analysis of chimeric A1/A2a adenosine receptors. J Biol Chem 272: 337-344, 1997. https://doi.org/10.1074/jbc.272.1.337

OSMOND DA, INSCHO EW: P2X1 receptor blockade inhibits whole kidney autoregulation of renal blood flow in vivo. Am J Physiol Renal Physiol 298: F1360-1368, 2010. https://doi.org/10.1152/ajprenal.00016.2010

OSMOND DA, ZHANG S, POLLOCK JS, YAMAMOTO T, DE MIGUEL C, INSCHO EW: Clopidogrel preserves whole kidney autoregulatory behavior in ANG II-induced hypertension. Am J Physiol Renal Physiol 306 : F619-F628, 2014. https://doi.org/10.1152/ajprenal.00444.2013

OSSWALD H, MUHLBAUER B, VALLON V: Adenosine and tubuloglomerular feedback. Blood Purif 15: 243-252, 1997. https://doi.org/10.1159/000170342

PALMER BF: Disturbances in renal autoregulation and the susceptibility to hypertension-induced chronic kidney disease. Am J Med Sci 328: 330-343, 2004. https://doi.org/10.1016/s0002-9629(15)33943-4

PALYGIN O, LEVCHENKO V, EVANS LC, BLASS G, COWLEY AW JR, STARUSCHENKO A: Use of enzymatic biosensors to quantify endogenous ATP or $\mathrm{H}_{2} \mathrm{O}_{2}$ in the kidney. J Vis Exp 104: e53059, 2015. https://doi.org/10.3791/53059

PALYGIN O, EVANS LC, COWLEY AW JR, STARUSCHENKO A: Acute in vivo analysis of ATP release in rat kidneys in response to changes of renal perfusion pressure. J Am Heart Assoc 6: pii: e006658, 2017. https://doi.org/10.1161/jaha.117.006658

PETI-PETERDI J: Calcium wave of tubuloglomerular feedback. Am J Physiol Renal Physiol 291: F473-F480, 2006. https://doi.org/10.1152/ajprenal.00425.2005 
PLOTH DW, ROY RN, HUANG WC, NAVAR LG: Impaired renal blood flow and cortical pressure autoregulation in contralateral kidneys of Goldblatt hypertensive rats. Hypertension 3: 67-74, 1981. https://doi.org/10.1161/01.hyp.3.1.67

REN Y, ARIMA S, CARRETERO OA, ITO S: Possible role of adenosine in macula densa control of glomerular hemodynamics. Kidney Int 61: 169-176, 2002. https://doi.org/10.1046/j.1523-1755.2002.00093.x

REN Y, GARVIN JL, LIU R, CARRETERO OA: Crosstalk between the connecting tubule and the afferent arteriole regulates renal microcirculation. Kidney Int 71: 1116-1121, 2007. https://doi.org/10.1038/sj.ki.5002190

ROMAN RJ: Abnormal renal hemodynamics and pressure-natriuresis relationship in Dahl salt-sensitive rats. Am J Physiol 251: F57-F65, 1986. https://doi.org/10.1152/ajprenal.1986.251.1.f57

ROMAN RJ, SMITS C: Laser-Doppler determination of papillary blood flow in young and adult rats. Am J Physiol 251: F115-F124, 1986. https://doi.org/10.1152/ajprenal.1986.251.1.f115

SCHJOEDT KJ, CHRISTENSEN PK, JORSAL A, BOOMSMA F, ROSSING P, PARVING HH: Autoregulation of glomerular filtration rate during spironolactone treatment in hypertensive patients with type 1 diabetes: a randomized crossover trial. Nephrol Dial Transplant 24: 3343-3349, 2009. https://doi.org/10.1093/ndt/gfp311

SCHNACKENBERG CG: Physiological and pathophysiological roles of oxygen radicals in the renal microvasculature. Am J Physiol Regul Integr Comp Physiol 282: R335-R342, 2002. https://doi.org/10.1152/ajpregu.00605.2001

SCHNERMANN J: Concurrent activation of multiple vasoactive signaling pathways in vasoconstriction caused by tubuloglomerular feedback: a quantitative assessment. Annu Rev Physiol 77: 301-322, 2015. https://doi.org/10.1146/annurev-physiol-021014-071829

SCHNERMANN J, WRIGHT FS, DAVIS JM, VON STACKELBERG W, GRILL G: Regulation of superficial nephron filtration rate by tubulo-glomerular feedback. Pflugers Arch 318: 147-175, 1970. https://doi.org/10.1007/bf00586493

SCHNERMANN J, WEIHPRECHT H, BRIGGS JP: Inhibition of tubuloglomerular feedback during adenosine1 receptor blockade. Am J Physiol 258: F553-F561, 1990. https://doi.org/10.1152/ajprenal.1990.258.3.f553

SCHWIEBERT EM: ATP release mechanisms, ATP receptors and purinergic signalling along the nephron. Clin Exp Pharmacol Physiol 28: 340-350, 2001. https://doi.org/10.1046/j.1440-1681.2001.03451.x

SEBELIUS K, FRIEDEN TR, SONDIK EJ: National Center for Health Statistics. Health, United States, 2011: Table 70 Hypertension among persons 20 years of age and over. 2011.

SHARMA K, COOK A, SMITH M, VALANCIUS C, INSCHO EW: TGF-beta impairs renal autoregulation via generation of ROS. Am J Physiol Renal Physiol 288: F1069-F1077, 2005. https://doi.org/10.1152/ajprenal.00345.2004

SOMMERS SC, RELMAN AS, SMITHWICK RH: Histologic studies of kidney biopsy specimens from patients with hypertension. Am J Pathol 34: 685-715, 1958.

SORENSEN CM, GIESE I, BRAUNSTEIN TH, BRASEN JC, SALOMONSSON M, HOLSTEIN-RATHLOU NH: Role of connexin 40 in the autoregulatory response of the afferent arteriole. Am J Physiol Renal Physiol 303: F855-F863, 2012. https://doi.org/10.1152/ajprenal.00026.2012

SUN D, SAMUELSON LC, YANG T, HUANG Y, PALIEGE A, SAUNDERS T, BRIGGS J, SCHNERMANN J: Mediation of tubuloglomerular feedback by adenosine: evidence from mice lacking adenosine 1 receptors. Proc Natl Acad Sci U S A 98: 9983-9988, 2001. https://doi.org/10.1073/pnas.171317998

TAKENAKA T, FORSTER H, DE MICHELI A, EPSTEIN M: Impaired myogenic responsiveness of renal microvessels in Dahl salt-sensitive rats. Circ Res 71: 471-480, 1992. https://doi.org/10.1161/01.res.71.2.471

TAKENAKA T, HARRISON-BERNARD LM, INSCHO EW, CARMINES PK, NAVAR LG: Autoregulation of afferent arteriolar blood flow in juxtamedullary nephrons. Am J Physiol Renal Physiol 267: F879-F887, 1994. https://doi.org/10.1152/ajprenal.1994.267.5.f879

THOMSON S, BAO D, DENG A, VALLON V: Adenosine formed by 5'-nucleotidase mediates tubuloglomerular feedback. J Clin Invest 106: 289-298, 2000. https://doi.org/10.1172/jci8761

TUCKER AL, LINDEN J: Cloned receptors and cardiovascular responses to adenosine. Cardiovasc Res 27: 62-67, 1993. https://doi.org/10.1093/cvr/27.1.62 
TURNER CM, VONEND O, CHAN C, BURNSTOCK G, UNWIN RJ: The pattern of distribution of selected ATP-sensitive P2 receptor subtypes in normal rat kidney: an immunohistological study. Cells Tissues Organs 175: 105-117, 2003. https://doi.org/10.1159/000073754

VALLON V, UNWIN RJ, INSCHO EW, LEIPZIGER J, KISHORE BK: Extracellular nucleotides and P2 receptors in renal function. Physiol Rev 100: 211-269, 2020. https://doi.org/10.1152/physrev.00038.2018

VON KUGELGEN I: Pharmacology of P2Y receptors. Brain Res Bull 151: 12-24, 2019. https://doi.org/10.1016/j.brainresbull.2019.03.010

VONEND O, TURNER CM, CHAN CM, LOESCH A, DELL'ANNA GC, SRAI KS, BURNSTOCK G, UNWIN RJ: Glomerular expression of the ATP-sensitive P2X receptor in diabetic and hypertensive rat models. Kidney Int 66: 157-166, 2004. https://doi.org/10.1111/j.1523-1755.2004.00717.x

WANG X, LOUTZENHISER RD, CUPPLES WA: Frequency modulation of renal myogenic autoregulation by perfusion pressure. Am J Physiol Regul Integr Comp Physiol 293: R1199-R1204, 2007. https://doi.org/10.1152/ajpregu.00281.2007

WANG X, TAKEYA K, AARONSON PI, LOUTZENHISER K, LOUTZENHISER R: Effects of amiloride, benzamil, and alterations in extracellular $\mathrm{Na}^{+}$on the rat afferent arteriole and its myogenic response. Am $\mathrm{J}$ Physiol Renal Physiol 295: F272-F282, 2008. https://doi.org/10.1152/ajprenal.00200.2007

WILCOX CS: Redox regulation of the afferent arteriole and tubuloglomerular feedback. Acta Physiol Scand 179: 217-223, 2003. https://doi.org/10.1046/j.0001-6772.2003.01205.x

ZHAN Y, BROWN C, MAYNARD E, ANSHELEVICH A, NI W, HO IC, OETTGEN P: Ets-1 is a critical regulator of Ang II-mediated vascular inflammation and remodeling. J Clin Invest 115: 2508-2516, 2005. https://doi.org/10.1172/jci24403

ZOU AP, LI N, COWLEY AW JR: Production and actions of superoxide in the renal medulla. Hypertension 37: 547-553, 2001 https://doi.org/10.1161/01.hyp.37.2.547 